\title{
CYCLIC OSCILLATIONS BETWEEN A SUMMER-ANNUAL \\ (C-4) AND A WINTER-ANNUAL WEED GRASS IN WAIKATO DAIRY PASTURES
}

\author{
D.A. WARDLE, G.M. BARKER, K.S. NICHOLSON \\ and P.J. ADDISON
}

AgResearch, Ruakura Agricultural Research Centre, Private Bag 3123, Hamilton

\section{SUMMARY}

The annual C-4 species summer grass (Digitaria sanguinalis) is increasingly being recognised as a problem in Waikato dairy pastures. We analysed botanical composition data collected in two $2^{1 / 2}-$-year small-plot field experiments to identify relationships between summer grass and the winter-active grass annual poa (Poa annua). In both studies, plots which contained high summer levels of summer grass contained high winter levels of annual poa, and this relationship strengthened with increasing duration of the experiments, indicating that both species occupy similar niches at different times of the year. It appears that summer grass and annual poa undergo cyclic oscillations, and that these species exclude other species from colonising the gaps they occupy.

Keywords: annual poa, Digitaria sanguinalis, gap dynamics, Poa annua, summer grass.

\section{INTRODUCTION}

In dairying regions of the northern half of the North Island invasive annual summe (C-4) grasses are often prevalent and may contribute to the restriction of forage supply and quality during the critical early-spring and late-summer periods. Appreciation of the extent of this problem is relatively recent and there is very little information on factors regulating $\mathrm{C}-4$ grass populations, or strategies for managing this problem (Woods and Andrewes 1990; Campbell and Hay 1993; Campbell and Wardle 1994). In the Waikato the most problematic annual species is summer grass (Digitaria sanguinalis). Many of these Waikato dairy pastures also contain high densities of annual poa (Poa annua), a winter-active grass. Their presence and success in the same pastures raises the possibility that winter-active and summer-active annual grasses may occupy the same or similar niches at different times of the year. This paper presents an analysis of data collected from three previous studies, with the aim of determining whether a linkage exists between the occurrence of summer grass and
annual poa.

\section{Experiment 1}

\section{METHODS}

This study was initially established to investigate aspects of demography of nodding thistle (Carduus nutans), in a dairy pasture located near Ohaupo ( $15 \mathrm{~km}$ from Hamilton) on a Horotiu sandy loam; full details of the site and experiment are given in Wardle et al. (1994). Briefly, the pasture was killed by application of the herbicides glyphosate (Roundup) and tribenuron-methyl (Granstar) on 19 March 1990. Eleven treatments consisting of monocultures of six grass species [Yorkshire fog (Holcus lanatus), perennial ryegrass (Lolium perenne), cocksfoot (Dactylus glomerata), prairie grass (Bromus wildenowii), phalaris (Phalaris aquatica) and tall fescue (Festuca arundinacea)], four legume species [white clover (Trifolium repens), red clover (T. pratense), subterranean clover (T. subterraneum) and lucerne (Medicago sativa)] and a bare-ground "control" were established by direct drilling on 2 April Proc. 47th N.Z. Plant Protection Conf. 1994: 34-37 
1990. There were four replicate plots, each $3.8 \times 3.8 \mathrm{~m}$, of each treatment. For all treatments except bare-ground, a $2 \times 1 \mathrm{~m}$ subplot was established in each plot and all emerging thistles removed. Pasture botanical composition was measured in each subplot using point quadrat analysis (total number of hits per species per 100 points) approximately every 3 months until 22 June 1992 . For the purposes of the present analyses, the data for summer grass and annual poa collected from the 40 planted plots were used.

\section{Experiment 2}

This study was initially conducted to investigate the impact of Argentine stem weevil (Listronotus bonariensis) infestation on ryegrass herbage production in a sheep-grazed pasture at Rukuhia (10 km from Hamilton) on Horotiu sandy loam; full site and experimental details are given in Barker et al. (1986). Briefly, a cultivated seed-bed was prepared, and four treatments were established on six replicate $8 \times 50 \mathrm{~m}$ plots in May 1981 by sowing four different ryegrass cultivars ("Grasslands Manawa", "Grasslands Nui", "NZ Perennial" and "Ellett") each with "Grasslands Huia" white clover. For all plots, tiller densities of all species present were estimated from 3048 mm diameter turf plugs per plot at 1-3 monthly intervals until 26 July 1983. For the present analysis, tiller count data collected over the 24 plots were used.

Survey

A survey was undertaken involving 63 paddocks (sites) on 11 farms (locations) of farmer-sown pasture in the Waikato, the details of which are given in Barker et al. (1986). In September 1982 and again in February 1983, tiller densities of all grass species were estimated from 50 randomly located $48 \mathrm{~mm}$ diameter plugs per site. Analyses

For data from all three studies, regression analyses were used to relate summer grass to annual poa levels in the previous winter/spring, and annual poa levels to summer grass in the previous summer.

\section{RESULTS AND DISCUSSIONS}

Relationships between annual poa and summer grass were significantly positive for all but one of the eight comparisons made in Experiments 1 and 2 (Figs. 1,2). Our data therefore suggest that pasture plots with a high summer grass component in the warmer months tend to also have a high annual poa content during the winter, indicative of an oscillation between the two species at least at a spatial scale equivalent to plot size. It is also apparent from Figs. 1 and 2 that the associations between annual poa and summer grass were strengthened over time in both experiments (an increase in $r$ occurs consistently over time) meaning that as the sown pasture developed and approached a state of longer-term equilibrium, the two species occupied increasingly similar habitats, and thus were only separable along the temporal niche axis. It is possible that occupation of pasture gaps by annual poa excludes ingress into these gaps by sown species such as ryegrass and white clover [see Wardle et al. (1994) for a similar mechanism by annual poa against nodding thistle (C. nutans)]. Such a situation would favour maintenance of gaps for summer grass colonisation following death of annual poa in the early summer. Whether oscillations between the two grasses actually excludes other species from utilising these gaps over several years is the subject of recently initiated field experiments. It is also highly apparent from both Figs. 1 and 2 that the content of both grasses increases over time, presumably at the expense of other species. Gaps occupied by annual poa/summer grass are therefore likely to serve as foci for the spread of these species throughout pasture.

Although our data show strong niche overlap between the two species at different seasons, this overlap is not entire. In Experiment 1, the use of multiple regression demonstrated that annual poa content (winter 1992) was a'function of both previous summer grass content (summer 1991-1992) and previous annual poa content (winter 1991), with each explaining a different component of the total variation $(r=0.615$, $\mathrm{P}<0.001$ ). Similarly, summer grass content (summer 1991-1992) was significantly determined by both previous annual poa (winter 1991) and previous summer grass content (summer 1990-1991) $(\mathrm{r}=0.656, \mathrm{P}<0.001)$. In experiment 2 , annual poa 

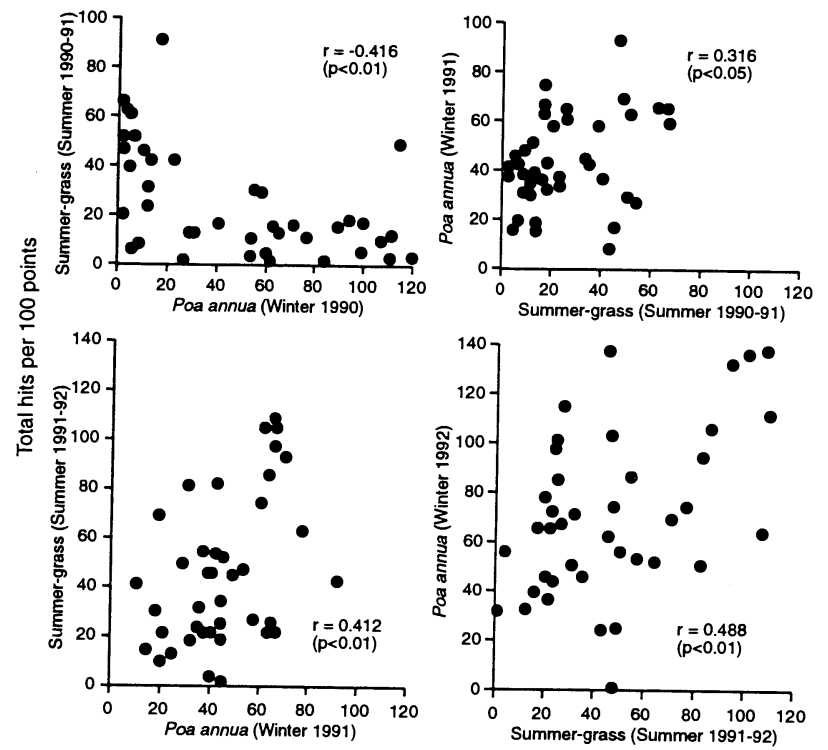

Total hits per 100 points

Figure 1: Temporal relationships between annual poa and summer grass in Experiment 1.

content in the second year (26 July 1983) was shown to be a function of previous summer grass content (Fig. 2) but not that of previous annual poa. However, summer grass (27 January 1983) was a function of both previous annual poa (19 July 1982) and previous summer grass $(12$ February 1982$)(\mathrm{r}=0.823, \mathrm{P}<0.001)$. The observation that spatial variation in abundance in each species was related to both the spatial variation in abundance of the other species 6 months earlier and its own abundance 12 months earlier may indicate not only slightly differing habitat requirements of the two species, but also that annual grass weed problems are likely to be recurrent on the same plots each year. This is to be expected if the success of each species is at least partially dependent on densities of seeds produced by previous generations.

While our results demonstrate a likely relationship between the two grass species at a within-field level, this was not apparent at a regional level. The survey data collected over 11 locations demonstrated a non-significant relationship between the two species when each location was treated as one independent data point $(\mathrm{r}=0.550$, $\mathrm{P}=0.079, \mathrm{n}=11)$. There was some evidence in the survey data that soil type was important in determining annual poa-summer grass interactions. Four of the eleven locations had sufficient site measurements $(\geq 8)$ to analyse within-location relationships. Two locations were on a Horotiu sandy loam and correlations between annual poa (September 1982) and summer grass (February 1983) pasture content at each location were extremely strong $(r=0.958$ and $0.948 ; n=16$ and $8 ; P<0.001$ and $<0.001$, respectively). At the other two locations associations between the two species was non-significant, ie. on Ohaupo silt loam $(r=0.308 ; n=9 ; \mathrm{P}=0.420)$ and on Rukuhia peaty loam $(r=0.693, n=8, P=0.057)$. Since experiments 1 and 2, depicted in Figs. 1 , 2 , were also on Horotiu sandy loam, it is apparent that all four locations on this soil type showed a significant relationship between annual poa and summer grass, while the other two locations on a different soil type did not.

The C-4 grass problem is linked to the dynamics of pasture vegetation gaps, and is therefore similar in nature to other ephemeral weed problems (Panetta and Wardle 1992). We are unsure at this stage as to whether the two species are effective in 


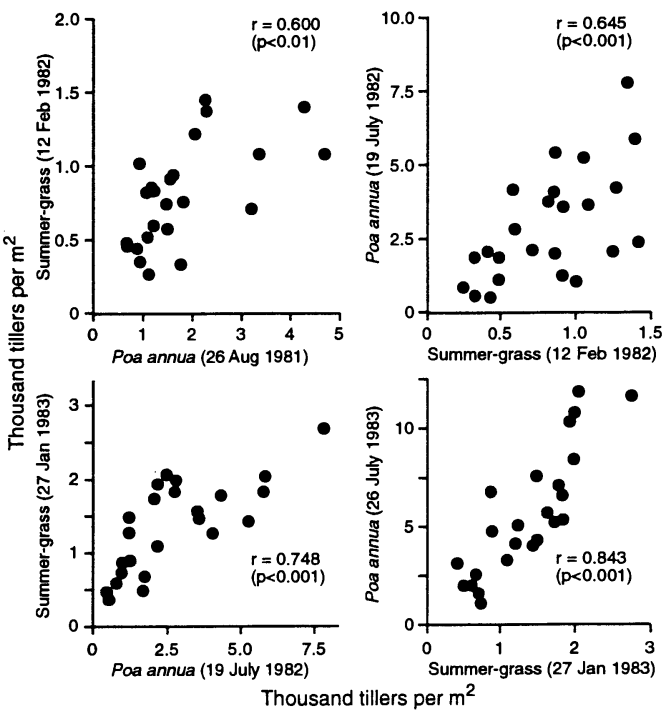

Figure 2: Temporal relationships between annual poa and summer grass in Experiment 2.

excluding other species from establishing and thus oscillate in the same gaps, although in the light of our results this appears likely. Our results indicate strongly that on Horotiu sandy loam (and possibly other free draining soils) in the Waikato there is a consistent relationship between summer grass and annual poa, and that these species occupy similar niches at different times of the year.

\section{ACKNOWLEDGEMENTS}

We thank M. Ahmed for technical assistance, R. Ward for the use of land for Experiment 1 , and $\mathrm{P}$. Hunt for preparing the figures.

\section{REFERENCES}

Barker, G.M., Prestidge, R.A. and Pottinger, R.P., 1986. Strategies for Argentine stem weevil control : effects of drought and endophyte. Proc. N.Z. Grassl. Assoc. 47: 107-114.

Campbell, B.D. and Hay, R.J.M., 1993. Will subtropical grasses continue to spread through New Zealand? Proc. 17th International Grassl. Congr.: 1126-1128.

Campbell, B.D. and Wardle, D.A., 1994. Report on 1993 Research Workshop on Subtropical Grass Invasion of North Island Dairy Pastures. Ruakura Agricultural Research Centre, Hamilton.

Panetta, F.D. and Wardle, D.A., 1992. Gap size and regeneration in a New Zealand dairy pasture. Aust. J. Ecol. 17: 169-175.

Wardle, D.A., Nicholson, K.S., Ahmed, M. and Rahman, A., 1994. Influence of pasture forage species on seedling emergence, growth and development of Carduus nutans L. J. Appl. Ecol. (in press).

Woods, P.W. and Andrewes, W.G.K., 1990. Subtropical (C-4) grasses as an Index of Climate Change. Report to the Ministry for the Environment. Kaikohe Research Station, Kaikohe. 